\title{
Degreening Buah Jeruk Siam (Citrus nobilis) pada Beberapa Konsentrasi dan Durasi Pemaparan Etilen
}

\author{
Degreening Siam Tangerine Fruit (Citrus nobilis) in Ethylene Concentrations and \\ Exposure Durations
}

\author{
Nian Rimayanti Hasimi ${ }^{1}$, Roedhy Poerwanto ${ }^{1}$, dan Ketty Suketi ${ }^{*}$ \\ Diterima 18 Maret 2016/Disetujui 06 Juli 2016
}

\begin{abstract}
Siam tangerine peel is green when harvested. Degreening technology by ethylene can improve the citrus peel color becomes uniformly orange. Degreening is a process to break down green pigment (chlorophyll) on citrus peel chemically and form the orange color (carotene) without affecting internal quality of fruit. The purpose of this research was to determine the effect of ethylene concentration and ethylene exposure duration to bring out the color on Siam tangerine from Banyuwangi. Ethylene 0, 100, 200 ppm was injected into the box containing $2.8 \mathrm{~kg}$ citrus and was exposed to the cooling chamber with a temperature $18{ }^{\circ} \mathrm{C}$ for 24 hours ethylene +48 hours without ethylene, 48 hours ethylene +24 hour without ethylene and 72 hours ethylene. Ethylene exposure was conducted using multiple shots method. After exposure, tangerines were put at room temperature condition. Observations were conducted every two days: (a) non-destructive observation conducted using color reader to determine the color changes; $(b)$ destructive observations for measuring chlorophyll and carotenoids content and physico-chemical changes i.e. the hardness, soluble solid content, titratable acidity and vitamin $C$. The results showed that the best combination was 200 ppm ethylene concentration for 48 hours ethylene exposure. This degreening technique altered the Citrus Colour Index (CCI) value from -1.60 to be 6.50, changed the tangerines into a bright orange. Degreening did not give negative impact on internal quality.
\end{abstract}

Key words: carotenoid, chlorophyll, citrus color index, cooling chamber, tropical citrus

\begin{abstract}
ABSTRAK
Warna kulit buah jeruk siam saat dipanen umumnya hijau. Teknologi degreening menggunakan gas etilen dapat memperbaiki warna kulit jeruk tropika menjadi jingga. Degreening merupakan proses perombakan pigmen hijau (klorofil) pada kulit jeruk secara kimiawi dan membentuk warna jingga (karotenoid) tanpa mempengaruhi kualitas internal buah. Penelitian bertujuan mengkaji pengaruh konsentrasi dan durasi pemaparan etilen untuk menstimulasi pigmen jingga dan pengaruhnya terhadap sifat fisikokimia jeruk siam Banyuwangi. Degreening jeruk menggunakan etilen 0,100 , dan 200 ppm diinjeksikan ke dalam box degreening yang berisi jeruk 2.8 $\mathrm{kg}$ dan dipaparkan pada cooling chamber dengan suhu $18^{\circ} \mathrm{C}$ selama 24,48 , dan 72 jam. Pengamatan dilakukan setiap dua hari: (a) pengamatan non-destruktif dengan menggunakan color reader untuk mengetahui perubahan warna; (b) pengamatan destruktif dengan mengukur kekerasan, kandungan klorofil dan karotenoid, Padatan Terlarut Total (PTT), Asam Tertitrasi Total (ATT) dan vitamin C untuk mengetahui perubahan fisikokimia jeruk. Hasil penelitian menunjukkan perubahan warna kulit buah mulai terjadi pada hari ke 4 setelah perlakuan degreening. Konsentrasi etilen terbaik adalah 200 ppm dengan durasi pemaparan 48 jam yaitu dapat meningkatkan kualitas warna buah jeruk siam dari hijau menjadi jingga kekuningan dan mampu mengubah nilai Citrus Colour Index (CCI) dari -1.60 (hijau) menjadi 6.50 (jingga kekuningan), tanpa pengaruh negatif terhadap kualitas fisikokimia buah.
\end{abstract}

Kata kunci: cooling chamber, citrus color index, jeruk tropika, karotenoid, klorofil

${ }^{1}$ Departemen Agronomi dan Hortikultura, Fakultas Pertanian, Institut Pertanian Bogor (Bogor Agricultural University) Jl. Meranti Kampus Darmaga, Bogor 16680 Indonesia. Telp/ Faks. 62-251-8629353

email: kettysuketi@yahoo.com (*penulis korespondensi) 


\section{PENDAHULUAN}

Jeruk siam merupakan buah yang potensial untuk dikembangkan sebagai upaya pemenuhan permintaan konsumen. Sekitar 70 sampai $80 \%$ jenis jeruk yang dikembangkan petani Indonesia merupakan jeruk siam (Dimyati, 2015). Jeruk siam digemari karena memiliki rasa yang manis dan mengandung vitamin $\mathrm{C}$ yang cukup tinggi. Jeruk siam memiliki permukaan kulit yang halus dan mengkilap. Pada tahun 2010, volume jeruk yang diimpor Indonesia mencapai 204148 ton, sedangkan volume jeruk yang diekspor hanya 1400 ton dengan produksi normal mencapai 1 937773 ton (BPS, 2011). Mutu buah merupakan hal penting terutama untuk pemasaran luar negeri. Secara visual, mutu jeruk lokal masih tergolong rendah karena kulit buah umumnya berwarna hijau kekuningan dan tidak seragam walaupun telah matang (Ladaniya, 2008). Menurut Poerwanto dan Susila (2014) kulit buah jeruk yang berwarna jingga mempunyai daya tarik yang lebih tinggi dibandingkan dengan kulit buah yang berwarna hijau.

Pembentukan warna kulit buah jeruk dipengaruhi oleh suhu rendah dan perubahan suhu pada saat proses pematangan (Ladaniya, 2008; Jomori et al., 2010). Suhu siang yang lebih tinggi $\left(30{ }^{0} \mathrm{C}\right)$ dapat menghambat perkembangan warna, walaupun suhu malam sudah cukup rendah, suhu udara di bawah 13 ${ }^{0} \mathrm{C}$ menyebabkan perombakan klorofil dan pembentukan karotenid. Hasil penelitian kombinasi perlakuan degreening $\left(18{ }^{\circ} \mathrm{C}\right)$ dan suhu simpan dengan suhu ruang menunjukkan hasil yang berbeda nyata pada perubahan warna dengan nilai Citrus colour index tertinggi pada tiga varietas jeruk Keprok (Muthmainnah et al., 2014).

Teknologi yang banyak dilakukan untuk meningkatkan warna kulit buah jeruk tropika adalah degreening (Jomori et al., 2010). Degreening merupakan proses perombakan pigmen hijau (klorofil) pada kulit jeruk secara kimiawi dan sekaligus membentuk warna kuning jingga (karatenoid) pada kulit jeruk. Proses ini tidak berpengaruh terhadap bagian dalam jeruk seperti gula, asam dan jus (Pantastico, 1993). Proses degreening telah banyak dilakukan untuk menghasilkan warna kulit buah jeruk yang lebih menarik. Hasil penelitian sebelumnya melaporkan bahwa, degreening dengan etilen atau ethrel mengubah warna kulit buah jeruk dari warna hijau menjadi kuning (Napitupulu et al., 1990), sementara konsumen lebih menyukai buah jeruk dengan kulit buah yang berwarna jingga seragam karena buah jeruk berwarna kuning dianggap telah hampir busuk.

Peranan etilen dalam pewarnaan kulit buah jeruk terbagi menjadi 2 kategori yaitu proses degreening dan pembentukan karotenoid. Aplikasi etilen dapat menstimulasi pembentukan karotenoid seperti cryptoxanthin, $\beta$-citraurin, dan violaxanthin. Proses terbentuknya pigmen tersebut dipengaruhi oleh kondisi suhu. Degreening pada suhu ruang 28 sampai $29{ }^{\circ} \mathrm{C}$ menghambat pembentukan zat warna $\beta$-citraurin sehingga seringkali jeruk yang dihasilkan berwarna kuning. Degreening pada suhu rendah 18 sampai $20{ }^{\circ} \mathrm{C}$ dapat membentuk zat warna $\beta$-citraurin dan criptoxanthin secara bersamaan sehingga dapat menghasilkan warna jingga (Stewart dan Wheaton, 1972).

Keefektifan degreening dipengaruhi beberapa faktor diantaranya etilen, suhu, dan kultivar buah (Sdiri et al., 2012). Penggunaan etilen sebagai zat perangsang metabolik untuk mencapai warna eksternal buah dipengaruhi oleh konsentrasi dan durasi pemaparan (Martínez et al., 2008). Durasi pemaparan yang tepat akan menghasilkan warna jingga seragam pada kulit buah (Sdiri et al., 2012). Oleh karena itu, penerapan perlakuan degreening pada buah jeruk siam diharapkan dapat memperbaiki warna eksternal buah sehingga dapat bersaing dengan jeruk impor. Penelitian ini bertujuan mengkaji konsentrasi dan durasi pemaparan etilen yang terbaik dalam proses degreening untuk membentuk warna jingga pada kulit buah jeruk siam (Citrus nobilis).

\section{BAHAN DAN METODE}

\section{Bahan dan Alat}

Penelitian ini dilaksanakan di Laborartorium Pusat Kajian Hortikultura Tropika (PKHT) Institut Pertanian Bogor pada tanggal 30 Mei sampai 2 Juli 2014. Bahan yang digunakan adalah buah jeruk siam yang diperoleh dari petani di Banyuwangi, gas etilen, larutan $\mathrm{NaOH} 0.1 \mathrm{~N}$ dan indikator 
phenol ptialin (PP) untuk titrasi asam, larutan iodin $0.01 \mathrm{~N}$ dan indikator amilum 1\%. Alat yang digunakan adalah wadah degreening, cooling chamber, syringe, septum, selang plastik, timbangan digital, lilin, color reader, hardness tester, refraktometer, gelas ukur, erlenmeyer, pipet tetes, alat pemeras, buret, corong dan kamera.

\section{Metode Penelitian}

Metode degreening dilakukan dalam wadah tertutup yang berisi jeruk dengan berat $2.8 \mathrm{~kg}$. Wadah dimasukkan ke cooling chamber pada suhu $18{ }^{0} \mathrm{C}$ sebelum diinjeksikan. Injeksi gas etilen kedalam wadah dilakukan dengan metode multiple shot (setiap 24 jam) dengan durasi pemaparan sesuai perlakuan, setelah durasi pemaparan tercapai jeruk dikeluarkan kemudian disimpan pada suhu ruang $\left(28^{\circ} \mathrm{C}\right)$.

Pengamatan dilakukan dengan mengukur perubahan warna pada kulit dan perubahan sifat fisikokimia buah jeruk setiap dua hari. Perubahan warna kulit buah jeruk diukur dengan Minolta color reader. Hasil pengukuran dinyatakan dalam citrus color index (CCI) (Jimenez et al., 1981) dengan rumus CCI $=\left(1000 \mathrm{a}^{*}\right) / \mathrm{L}^{*} \mathrm{x} \mathrm{b}^{*}$. Range Citrus Color Index (CCI): $\mathrm{CCI}<=-5$ (hijau gelap), $5<\mathrm{CCI}<=0 \quad$ (hijau), $\quad 0<\mathrm{CCI}<=3 \quad$ (hijau kekuningan), $3<\mathrm{CCI}<=5$ (kuning kehijauan), $5<\mathrm{CCI}<=7$ (jingga kekuningan), $7<\mathrm{CCI}<=10$ (jingga), dan CCI $>10$ (jingga gelap). Hasil pengukuran nilai $a^{*}$ dan $b^{*}$ juga dikonversikan ke dalam satuan kromatik derajat hue (Lee, 2000; Manera et al., 2013) dengan rumus ${ }^{\circ}$ hue yaitu $\tan ^{-1}\left(\mathrm{~b}^{*} / \mathrm{a}^{*}\right)$. Kandungan total klorofil dan karotenoid diukur menggunakan metode spektofotometri (Andarwulan et al., 2011). Perubahan sifat fisikokimia yang diamati yaitu kekerasan buah, kandungan vitamin $\mathrm{C}$, asam tertitrasi total (ATT) dan padatan terlarut total (PTT).

\section{Rancangan Percobaan}

Penelitian ini menggunakan metode Rancangan Acak Lengkap Faktorial yang terdiri atas dua perlakuan yaitu konsentrasi etilen dan durasi pemaparan etilen. Konsentrasi etilen terdiri atas tiga taraf yaitu 0 ppm (E0), 100 ppm (E1) dan 200 ppm (E2). Durasi pemaparan terdiri atas tiga taraf yaitu 24 jam etilen +48 jam tanpa etilen (D1), 48 jam etilen +24 jam tanpa etilen (D2), dan 72 jam etilen (D3), sehingga terdapat 9 kombinasi perlakuan yang diulang sebanyak 3 kali dan terdapat 27 unit percobaan. Setiap unit percobaan menggunakan 20 buah jeruk, sehingga jumlah keseluruhan buah 790 buah jeruk. Data yang diperoleh kemudian dianalisis menggunakan analisis ragam pada taraf nyata 5\%. Data yang berbeda nyata diuji lanjut dengan duncan multiple range test (DMRT) pada taraf $5 \%$.

\section{HASIL DAN PEMBAHASAN}

\section{Karakteristik Jeruk Siam Banyuwangi sebelum Degreening}

Jeruk siam Banyuwangi dipanen pada umur 28 minggu setelah antesis (MSA) dengan diameter rata-rata $64.3 \mathrm{~mm}$, sehingga tergolong dalam grade $\mathrm{B}$ yaitu dengan diameter 61 sampai $70 \mathrm{~mm}$ menurut Standar Nasional Indonesia. Hasil analisis mutu awal buah jeruk siam Banyuwangi sebelum degreening disajikan pada Tabel 1.

Pengukuran mutu awal buah jeruk siam Banyuwangi menggunakan tiga ulangan. Hasil pengukuran menunjukkan bahwa warna jeruk siam Banyuwangi cenderung berwarna hijau dengan nilai rata-rata $a^{*} 3.29, b^{*} 24.26$. Derajat kecerahan $\left(\mathrm{L}^{*}\right)$ jeruk siam Banyuwangi cukup rendah yaitu 40.58, CCI 1.06 , 'hue 97.68 dan memiliki skor 1 yang secara fisik berwarna hijau.

Tabel 1. Karakteristik jeruk siam sebelum degreening

\begin{tabular}{lllr}
\hline Komponen & Rerata & Komponen & Rerata \\
\hline Derajat kecerahan $\left(\mathrm{L}^{*}\right)$ & 40.58 & ${ }^{\circ}$ hue & 97.68 \\
Derajat warna hijau $\left(\mathrm{a}^{*}\right)$ & -3.29 & Kekerasan $(\mathrm{Kg} /$ detik $)$ & 0.73 \\
Derajat warna kuning $\left(\mathrm{b}^{*}\right)$ & 24.26 & PTT $\left({ }^{\circ} \mathrm{Brix}\right)$ & 10.38 \\
CCI & -1.06 & ATT $(\%)$ & 0.58 \\
Skor & 1 & Vitamin C $(\mathrm{mg} / 100 \mathrm{~g})$ & 37.70 \\
Diameter $(\mathrm{mm})$ & 64.3 & & \\
\hline
\end{tabular}


Rata-rata tingkat kekerasan buah jeruk siam Banyuwangi adalah $0.73 \mathrm{~kg} /$ detik yang menunjukkan bahwa buah jeruk masih memiliki tekstur yang keras. Kandungan ratarata padatan terlarut total yaitu $10.38{ }^{\circ}$ brix. Hal ini menggambarkan kandungan gula buah jeruk cukup tinggi dan menyebabkan buah jeruk memiliki rasa manis. Menurut Ladaniya (2008) standar kematangan jeruk untuk daerah tropika yaitu memiliki nilai ${ }^{\circ}$ brix berkisar antara 9 sampai 10 dan masih berwarna hijau pada saat matang fisiologis.

\section{Karakteristik Warna Buah setelah Degreening}

Warna merupakan penentu utama kualitas buah jeruk siam. Warna kulit buah yang jingga seragam lebih disukai oleh konsumen. Teknologi degreening dengan aplikasi etilen pada penelitian ini dapat menstimulasi perubahan warna kulit buah jeruk siam dari hijau menjadi jingga kekuningan. Perubahan warna kulit pada buah mulai terjadi pada 4 hari setelah degreening (HSD) dan mencapai warna optimum pada 12 HSD (Tabel 2).

Konsentrasi etilen berpengaruh nyata terhadap nilai CCI, ${ }^{\circ}$ hue, total klorofil serta kandungan karotenoid buah jeruk siam Banyuwangi. Nilai CCI buah jeruk siam mengalami peningkatan seiring dengan tingginya konsentrasi etilen. Jeruk dengan aplikasi etilen 100 dan $200 \mathrm{ppm}$ mengalami peningkatan CCI yang lebih tinggi yaitu 5.02 dan 5.39 dengan warna yang dihasilkan berdasarkan range $\mathrm{CCI}$ adalah jingga kekuningan (Tabel 1), sedangkan buah jeruk tanpa aplikasi etilen memiliki nilai CCI terendah dengan warna yang dihasilkan adalah hijau semburat kuning. Aplikasi etilen dapat mempercepat peningkatan nilai CCI buah jeruk siam Banyuwangi yang menandakan buah mengarah kewarna jingga. Hal tersebut sejalan dengan Ladaniya (2008) yang menyatakan, degreening menggunakan etilen dapat mempercepat perombakan klorofil dan mempercepat perkembangan warna buah dengan meningkatkan sintesis karotenoid.

Warna kulit buah jeruk siam mencapai optimum pada 12 HSD (Tabel 2). Konsentrasi etilen 200 ppm menghasilkan nilai ${ }^{\circ}$ hue dan kandungan klorofil total terendah yang menunjukkan buah mengarah ke warna jingga.
Etilen berfungsi merangsang degradasi klorofil dan membentuk karotenoid pada kulit buah jeruk. Warna kulit buah tampak jingga kekuningan disebabkan karena hancurnya klorofil dan terakumulasinya karotenoid pada kulit buah. Degreening menggunakan etilen dapat mempercepat perombakan klorofil dan mempercepat perkembangan warna buah dengan meningkatkan sintesis karotenoid.

Konsentrasi etilen 200 ppm dengan durasi 48 jam menghasilkan warna paling optimum yaitu jingga kekuningan meskipun perubahan warna buah kulit berjalan lambat. Lambatnya degradasi klorofil diduga karena buah tidak dipaparkan langsung pada suhu ruang setelah proses degreening. Selain itu, perubahan warna yang lambat diduga karena suhu degreening yang kurang optimum. Hasil penelitian Mayuoni et al. (2011), jeruk mandarin Michal menunjukkan perubahan warna menjadi jingga seragam pada suhu 20 ${ }^{0} \mathrm{C}$ selama pemaparan $48 \mathrm{jam}$. Hasil yang sama diperoleh pada penelitian Ramadhani et al. (2015) menyatakan bahwa degreening menggunakan etilen pada suhu $20{ }^{\circ} \mathrm{C}$ selama 48 jam menghasilkan warna jingga cerah pada kulit buah jeruk siam Banyuwangi. Menurut Sdiri et al. (2012) keefektifan degreening dipengaruhi beberapa faktor, diantaranya etilen, suhu, dan kultivar buah.

\section{Pengaruh Degrening terhadap Citrus Color Index (CCI)}

Kombinasi perlakuan konsentrasi etilen dan durasi pemaparan etilen memiliki respon yang berbeda terhadap perubahan warna buah jeruk siam Banyuwangi (Gambar 1). CCI merupakan salah satu parameter yang digunakan untuk mengukur indeks warna buah jeruk. Semakin tinggi nilai CCI maka buah mengarah ke warna jingga.

Buah jeruk tanpa etilen mengalami sedikit perubahan warna yaitu dengan nilai CCI maksimum 4.62 pada durasi pemaparan etilen 48 jam yang menghasilkan warna hijau semburat kuning pada kulit buah jeruk siam Banyuwangi. Jeruk tanpa perlakuan etilen menunjukkan peningkatan nilai CCI yang lambat, berbeda dengan jeruk yang diberi perlakuan etilen yang menghasilkan warna jingga kekuningan pada kulit jeruk siam Banyuwangi. 
J. Hort. Indonesia 7(2): 111-120. Agustus 2016.

Tabel 2. Perubahan warna kulit buah jeruk siam Banyuwangi pada 12 HSD

\begin{tabular}{ccccc}
\hline Perlakuan & $\mathrm{CCI}$ & ${ }^{\circ} \mathrm{Hue}$ & $\begin{array}{c}\text { Klorofil } \\
(\mu \mathrm{g} / \mathrm{g})\end{array}$ & $\begin{array}{c}\text { Karotenoid } \\
(\mu \mathrm{g} / \mathrm{g})\end{array}$ \\
\hline Konsentrasi etilen $(\mathrm{ppm})$ & & & & \\
0 & $4.43 \mathrm{~b}$ & $74.60 \mathrm{~b}$ & $0.018 \mathrm{a}$ & $0.04 \mathrm{~b}$ \\
100 & $5.02 \mathrm{a}$ & $74.33 \mathrm{~b}$ & $0.006 \mathrm{a}$ & $0.05 \mathrm{a}$ \\
200 & $5.39 \mathrm{a}$ & $73.08 \mathrm{a}$ & $0.003 \mathrm{~b}$ & $0.06 \mathrm{a}$ \\
\hline Durasi pemaparan (jam) & & & & \\
24 & $3.79 \mathrm{~b}$ & 75.81 & $0.015 \mathrm{a}$ & 0.054 \\
48 & $5.50 \mathrm{a}$ & 74.93 & $0.007 \mathrm{~b}$ & 0.051 \\
72 & $5.58 \mathrm{a}$ & 74.28 & $0.005 \mathrm{~b}$ & 0.047 \\
\hline Interaksi & tn & tn & tn & tn \\
\hline
\end{tabular}

Keterangan: Angka rataan yang diikuti huruf yang sama pada kolom yang sama tidak berbeda nyata berdasarkan Uji DMRT pada taraf $5 \%$.

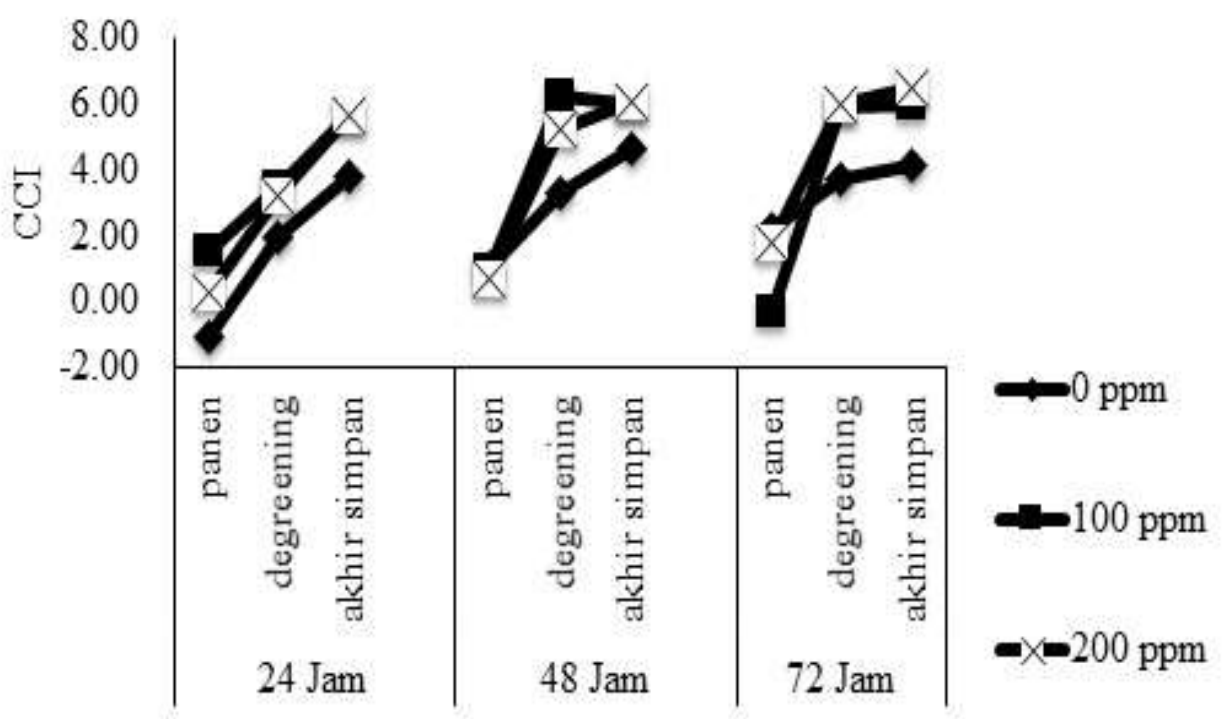

Gambar 1. Pola perubahan nilai CCI buah jeruk siam Banyuwangi setelah degreening

Nilai CCI tertinggi adalah 6.4 diperoleh pada perlakuan konsentrasi etilen $200 \mathrm{ppm}$ pada durasi 48 jam dan 72 jam yang menghasilkan jeruk siam dengan warna kulit jingga kekuningan, namun jeruk siam dengan pemaparan etilen 72 jam lebih cepat mengalami busuk dibandingkan dengan perlakuan lain sehingga durasi pemaparan etilen 48 jam ditetapkan sebagai durasi pemaparan etilen terbaik. Degreening menggunakan etilen dapat mempercepat perombakan klorofil dan mempercepat perkembangan warna buah dengan meningkatkan sintesis karotenoid. Menurut Ladaniya (2008) durasi pemaparan etilen juga dapat mempengaruhi perkembangan warna kulit buah jeruk.

\section{Pengaruh Degreening terhadap Perubahan Nilai ${ }^{\circ}$ Hue}

Nilai ${ }^{\circ}$ hue diperoleh dari hasil pengukuran $a^{*}$ dan $b^{*}$ yang dikonversi ke dalam satuan kromatik derajat hue ('hue). Degreening menggunakan etilen nyata menurunkan nilai ${ }^{\circ}$ hue pada buah jeruk siam. Nilai ${ }^{\circ}$ hue jeruk siam sebelum perlakuan sebesar 97.68 kemudian menurun dengan adanya perlakuan degreening menjadi 73.91 yang menunjukkan adanya perubahan warna dari warna hijau menjadi jingga kekuningan. Konsentrasi etilen 100 ppm dan 200 ppm sama baiknya dalam menurunkan nilai ${ }^{\circ}$ hue kulit buah jeruk siam. Hal tersebut sejalan dengan hasil penelitian sebelumnya yang menyatakan bahwa terjadi penurunan nilai ${ }^{\circ}$ hue pada kulit buah jeruk siam setelah degreening menggunakan etilen (Arzam et al., 2015; 
Ramadhani et al., 2015). Durasi pemaparan etilen 24 jam, 48 jam dan 72 jam dalam degreening sama baiknya dalam menurunkan nilai ${ }^{\circ}$ hue buah jeruk siam Banyuwangi, namun pada durasi pemaparan 72 jam buah jeruk mengalami pembusukan lebih cepat sehingga umur simpan menjadi lebih pendek.

Menurut Tanaka dan Tanaka (2006), etilen mempercepat degradasi klorofil dan mensintesis karotenoid sehingga warna hijau pada jeruk siam Banyuwangi dengan perlakuan 100 dan 200 ppm lebih cepat hilang dan digantikan oleh warna jingga kekuningan. Menurut Anggraini (2015), hilangnya klorofil pada kulit buah diakibatkan meningkatnya aktifitas klorofilase yang menguraikan klorofil menjadi bagian fitol dan inti profirin sehingga kulit jeruk tidak berwarna hijau lagi. Selain itu, struktur internal kloroplas terpecah selama degreening dengan etilen.

\section{Pengaruh Degreening terhadap Klorofil dan Karotenoid Total}

Kandungan klorofil dan karotenoid total berperan penting dalam pewarnaan buah. Perubahan warna dari hijau menjadi kuning atau jingga berhubungan dengan berkurangnya kandungan klorofil dan bertambahnya karotenoid. Kandungan klorofil dan karotenoid

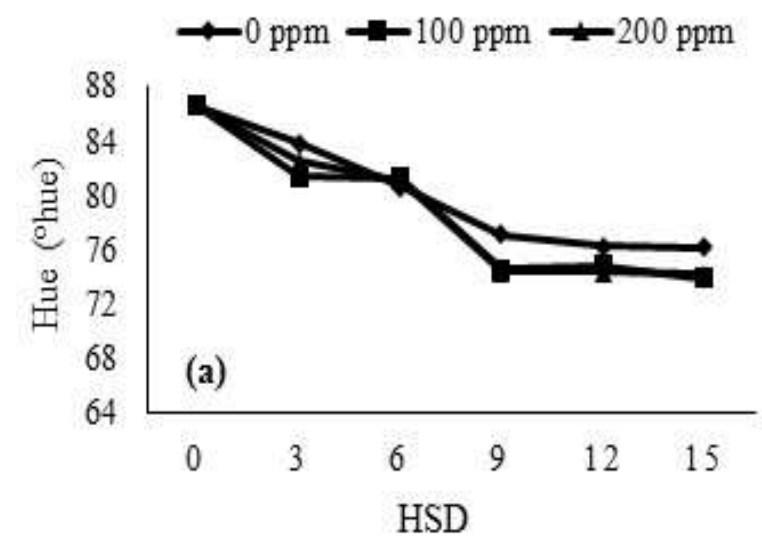

total kulit buah jeruk siam Banyuwangi disajikan pada Gambar 3 dan 4.

Kandungan klorofil total menurun secara bertahap selama penyimpanan. Pemberian etilen mempercepat penurunan klorofil total kulit jeruk. Kandungan klorofil total terendah diperoleh pada konsentrasi etilen $200 \mathrm{ppm}$ dengan durasi pemaparan 48 jam sebesar $0.0013 \mathrm{mg} / \mathrm{g}$. Kandungan klorofil total tertinggi diperoleh pada perlakuan tanpa etilen dan durasi pemaparan etilen 24 jam pada suhu degreening $18{ }^{\circ} \mathrm{C}$ yaitu sebesar 0.020 $\mathrm{mg} / \mathrm{g}$. Selama perkembangan buah jeruk, warna berubah menjadi jingga kekuningan berhubungan dengan berkurangnya kandungan klorofil total akibat degradasi. Menurut Peng et al. (2013), degradasi klorofil meningkat dengan adanya aplikasi degreening dengan etilen. Kandungan klorofil total dapat pula dipengaruhi oleh biosintesis klorofil, interkonversi klorofil a dan $b$ dan juga degradasi klorofil (Tanaka dan Tanaka, 2006). Menurunnya kandungan klorofil pada buah dengan perlakuan etilen disebabkan oleh peningkatan aktivitas chlorophyllase dan penurunan ukuran dan jumlah kloroplas pada kulit (Barmore, 1975; Shimokawa et al., 1998). Peningkatan chlorophyllase setelah proses degreening akan mempercepat degradasi klorofil.

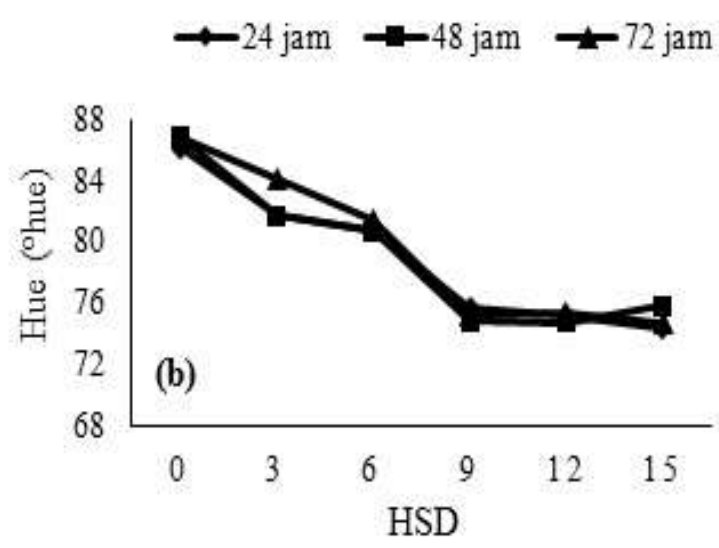

Gambar 2. Penurunan nilai hue buah jeruk siam Banyuwangi selama penyimpanan pada perlakuan (a) konsentrasi etilen dan (b) durasi pemaparan etilen 


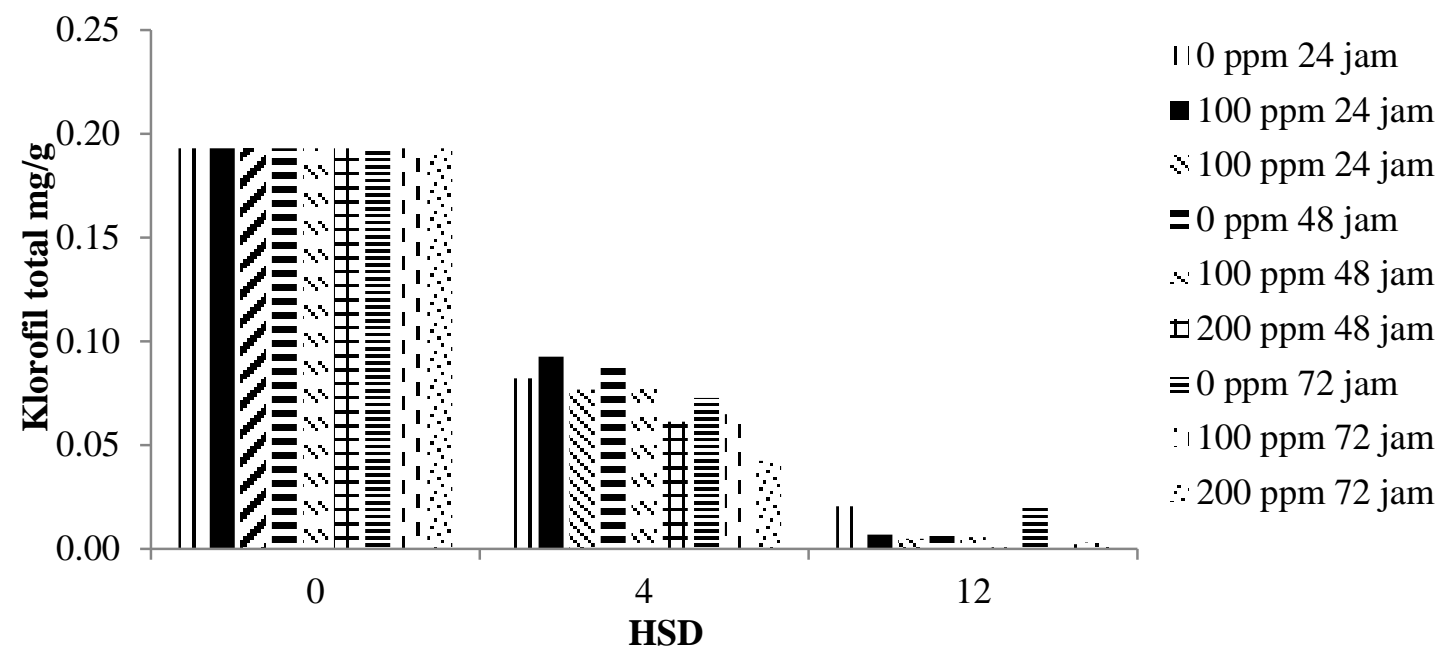

Gambar 3. Perubahan kandungan klorofil total kulit jeruk siam Banyuwangi pada berbagai konsentrasi dan durasi pemaparan etilen, $\mathrm{HSD}=$ hari setelah degreening.

Jeruk adalah sumber karotenoid yang kompleks dengan jumlah karotenoid terbesar ditemukan pada buah (Ladaniya, 2008). Selama pemaparan etilen, terjadi perombakan klorofil yang diikuti dengan pembentukan karotenoid pada kulit buah jeruk. Karotenoid total cenderung meningkat setelah degreening dan selama penyimpanan. Nilai kandungan karotenoid total tertinggi diperoleh pada konsentrasi etilen $200 \mathrm{ppm}$ dengan durasi pemaparan etilen 48 jam pada suhu $18^{0} \mathrm{C}$ yaitu sebesar $0.08 \mathrm{mg} / \mathrm{g}$. Matsumoto et al. (2009), menyatakan bahwa perlakuan degreening menggunakan etilen dapat meningkatkan nilai karotenoid pada kulit jeruk Satsuma. Stewart dan Wheaton (1972) melaporkan terjadinya peningkatan warna pada jeruk yang diberikan perlakuan etilen disebabkan oleh akumulasi dari karotenoid yang lebih spesifik seperti cryptoxanthin dan apocarotenoid $\mathrm{C} 30 \quad \beta$ citraurin, violaxanthin. Pada jeruk Ponkan akumulasi $\beta$-cryptoxanthin dan $\beta$-citraurin pada kulit buah menghasilkan warna jingga sedangkan violaxanthin menghasilkan warna kuning (Zhou et al., 2010). Perubahan warna kulit jeruk menjadi jingga disebabkan karena terjadinya sintesis karotenoid yang bersifat nonphotosintectic yaitu $\beta$-citraurin yang merupakan pembentuk warna jingga kemerahan pada kulit jeruk mandarin, akumulasi senyawa ini ditentukan oleh ketersediaan prekusor berupa karotenoid yang bersifat photosintetic seperti zeaxanthin dan $\beta$ cryptoxanthin (Kato et al., 2004; Rodrigo et al., 2013; Ma et al., 2013).

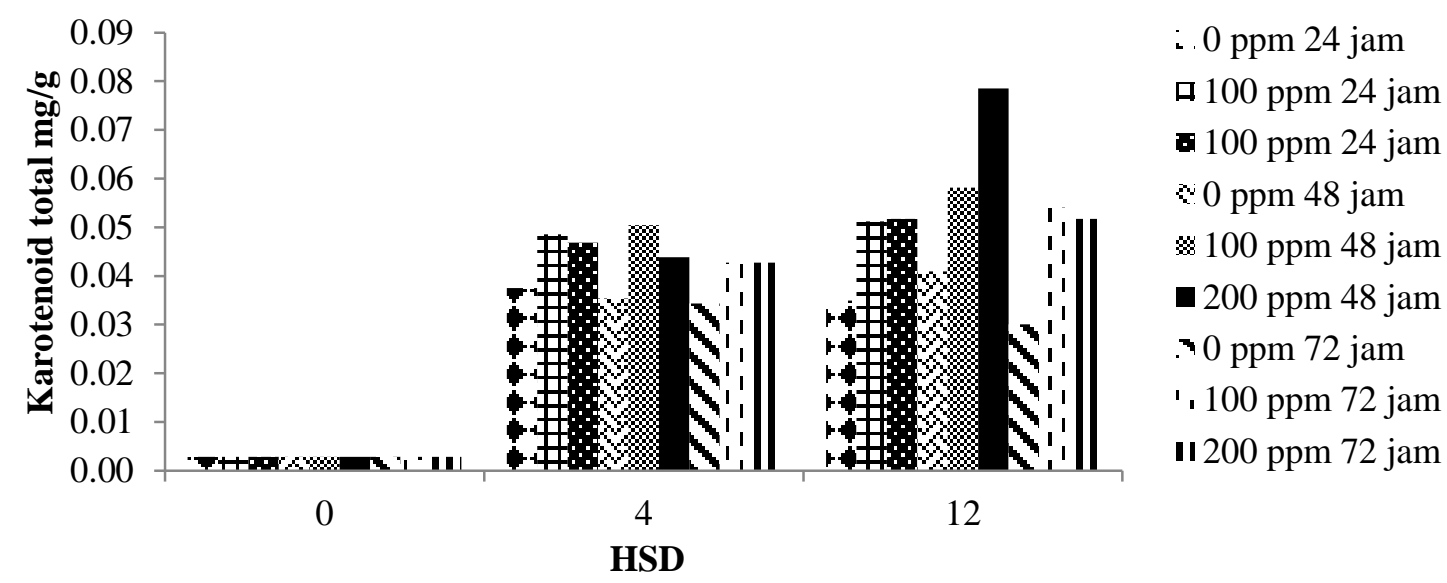

Gambar 4. Perubahan kandungan karotenoid total kulit jeruk siam Banyuwangi pada berbagai konsentrasi dan durasi pemaparan etilen 
Tabel 5. Sifat fisikokimia buah jeruk siam Banyuwangi pada berbagai kosentrasi dan durasi pemaparan etilen pada $12 \mathrm{HSD}$

\begin{tabular}{lcccc}
\hline Perlakuan & $\begin{array}{c}\text { Kekerasan } \\
(\mathrm{N})\end{array}$ & $\begin{array}{c}\text { PTT } \\
\left({ }^{\mathrm{O}} \mathrm{Brix}\right)\end{array}$ & $\begin{array}{c}\text { ATT } \\
(\mathrm{mg} / 100 \mathrm{~g})\end{array}$ & $\begin{array}{c}\text { Vitamin C } \\
(\mathrm{mg} / 100 \mathrm{~g})\end{array}$ \\
\hline Konsentrasi Etilen (ppm) & & & & \\
$\quad 0 \mathrm{ppm}$ & 0.63 & 10.30 & 4.54 & 45.14 \\
$100 \mathrm{ppm}$ & 0.62 & 11.19 & 4.44 & 43.37 \\
$\quad 200 \mathrm{ppm}$ & 0.64 & 8.56 & 4.14 & 34.86 \\
\hline Durasi & & & & \\
$\quad 24$ jam etilen + 48 jam tanpa etilen & 0.64 & 10.27 & 4.50 & 48.50 \\
$\quad 48$ jam etilen + 24 jam tanpa etilen & 0.64 & 8.57 & 4.64 & 34.32 \\
$\quad 72$ jam etilen & 0.61 & 11.21 & 3.98 & 40.45 \\
\hline Interaksi & tn & tn & tn & tn \\
\hline
\end{tabular}

\section{Pengaruh Degreening terhadap Perubahan Fisikokimia}

Sifat fisikokimia jeruk berhubungan dengan proses pematangan jeruk, baik yang berhubungan dengen proses dalam jaringan kulit, maupun proses pematangan internal dalam daging buah (Sdiri et al., 2012). Konsentrasi etilen dan durasi pemaparan etilen serta interaksi antar kedua perlakuan tidak berpengaruh nyata terhadap kandungan padatan terlarut total (PTT), asam tertitrasi total (ATT), vitamin C dan tingkat kekerasan buah jeruk siam Banyuwangi (Tabel 5). Pada penelitian sebelumnya telah dilaporkan bahwa pemberian etilen exogeneous menunjukkan perubahan fisik dan biokimia yang mirip dengan buah yang tidak beri perlakuan (Sdiri et al., 2012; Tietel et al., 2010).

Kandungan PTT buah jeruk meningkat selama penyimpanan dengan kisaran nilai PTT 8.56-11.27 ${ }^{\circ}$ brix pada 12 HSD, meskipun peningkatannya tidak berbeda nyata baik pada jeruk dengan maupun tanpa perlakuan etilen (Tabel 5). Hasil tersebut sejalan dengan penelitian Mayuoni et al. (2011), perlakuan etilen dapat meningkatkan kandungan PTT buah jeruk. Menurut Winarno (2002) kenaikan PTT terjadi karena karbohidrat terhidrolisis menjadi senyawa glukosa dan fruktosa, sedangkan penurunan PTT disebabkan gula sederhana mengalami perubahan menjadi alkohol, aldehid, dan asam.

Kandungan ATT buah jeruk siam Banyuwangi berkisar antara 3.98 sampai 4.64 $\mathrm{mg} / 100 \mathrm{~g}$. Nilai kandungan ATT cenderung menurun tetapi tidak untuk semua perlakuan. Kandungan ATT menurun pada buah yang diberikan perlakuan etilen, walaupun secara statistik tidak berbeda nyata dengan buah tanpa perlakuan etilen. Martínez-Jávega et al (2008) melaporkan bahwa kandungan ATT buah jeruk mengalami sedikit penurunan setelah proses degreening. Penurunan kandungan ATT disebabkan oleh penggunaan asam organik dalam siklus Kreb untuk memproduksi energi dan terjadinya konversi asam organik membentuk gula (Sulistyaningrum dan Susanto, 2004).

Vitamin C merupakan faktor kualitas nutrisi terpenting pada buah jeruk. Kandungan vitamin $\mathrm{C}$ dalam buah dapat dipengaruhi oleh berbagai faktor diantaranya perbedaan genotipe, kondisi iklim tempat tumbuh buah, perlakuan selama di kebun, kematangan dan metode pemanenan, serta prosedur penanganan pascapanen. Hasil analisis statistik menunjukkan bahwa tidak ada pengaruh yang nyata antara jeruk dengan perlakuan degreening dengan jeruk tanpa perlakuan etilen atau kontrol. Kandungan vitamin $\mathrm{C}$ buah jeruk siam berkisar antara 34.32 sampai 48.50 $\mathrm{mg} / 100 \mathrm{~g}$ pada akhir penyimpanan (12 HSD). Hal ini sesuai dengan penelitian Ladaniya (2008) yang menyatakan jeruk umumnya mengandung 40 sampai $70 \mathrm{mg}$ vitamin C/100g. Menurut Mayuoni et al. (2011) tidak ada perubahan nilai kandungan vitamin $C$ yang berarti pada jeruk Satsuma kontrol (tanpa perlakuan etilen) maupun yang diberi perlakuan degreening.

\section{KESIMPULAN}

Konsentrasi etilen 200 ppm dengan durasi pemaparan 48 jam merupakan perlakuan terbaik dalam proses degreening buah jeruk siam yang menghasilkan warna 
jingga kekuningan pada kulit buah jeruk siam Banyuwangi. Degreening tidak memberikan pengaruh nyata terhadap kualitas internal buah jeruk siam Banyuwangi.

\section{SARAN}

Penyimpanan pada suhu rendah setelah proses degreening sebaiknya dilakukan untuk memperpanjang masa simpan buah jeruk siam.

\section{DAFTAR PUSTAKA}

Andarwulan, N., F. Kusnandar, D. Herawati. 2011. Analisis Pangan. Jakarta, Dian Rakyat.

Anggraini, R., R. Hasbullah, Sutrisno. 2015. Studi degreening pada jeruk cultivar keprok madu Terigas Kalimantan Barat. J. Penelitian Pascapanen Pertanian. 12: 3-44.

Arzam, T.S., I. Hidayati, R. Poerwanto, Y.A. Purwanto. 2015. Precooling dan konsentrasi etilen dalam degreening untuk membentuk warna jingga kulit buah jeruk siam. J. Hort. 25(3): 257-265.

[BPS] Badan Pusat Statistik. 2011. Produksi Buah-buahan di Indonesia 2005-2011. Jakarta (ID).

Barmore, C.R. 1975. Effect of ethylene on chlorophyllase activity and chlorophyll content in calamondin rind tissue. HortScience. 10: 595-596.

Dimyati, A. 2005. Prospek dan arah pengembangan agribisnis jeruk. Badan Penelitian dan Pengembangan Pertanian. Kementrian Pertanian Republik Indonesia. Jakarta.

Jimenez, C.M., J. Cuquerella, M.J. Javega. 1981. Determination of a color index for citrus fruit degreening. Proc. Int. Soc. Citriculture. 2: 750-753.

Jomori, M.L.L., I. Sestari, F.A.M. Terra, D.G. Chiou, R.A. Klauge. 2010. Degreening of 'Murcott' tangor with ethepon treatments. Proc. IV International Postharvest Symposium. Acta Hort. 877: 815-820.

Kato, M., Y. Ikoma, H. Matsumoto, M. Sugiura, H. Hyodo, M. Yano. 2004. Accumulation of carotenoid and expression of carotenoid biosynthetic genes during maturation in citrus fruit. J. Plant Physiol. 134: 824-837.

Ladaniya, M.S. 2008. Citrus Fruit: Biology, Technology, and Evaluation. San Diego, Academic Press.

Lee, H.S. 2000. Objective measurement of red grapefruit juice color. J. Agric. Food Chem. 48: 1507-15011.

Ma, G., L. Zhang, A. Matsuta, K. Matsutani, M. Kazuki, M. Yahata, A. Wahyudi, R. Motohashi, M. Kato. 2013. Enzymatic formation of $\beta$-citraurin from $\beta$ cryptoxanthin dan zeaxanthin by carotenoid leavage dioxygenase in the flavedo of cs fruit. J. Plant Physiol. 163: 682-695.

Manera, F.J., J.M. Brotons, A. Conesa, I. Porras. 2013. Relation between temperature and the beginning of peel color change in grapefruit (Citrus paradisii Macf.). J. Sci. Hort. 160: 292-299.

Martínez-Jávega, J.M., A. Monterde. P. Navarro. A. Salvador. 2008. Respons of new clementines to degreening treatment. Proc. Int. Soc. Citriculture. 11: 1342-1346.

Matsumoto, H., Y. Ikoma, M. Kato, N. Nakajima, Y. Hasegawa. 2009. Effect of postharvest temperature and ethylene on carotenoid accumulation in the flavedo and juice sacs of Satsuma mandarin (Citrus unshiu Marc.) fruit. J Agric. Food Chem. 57: 4724-4732.

Mayuoni, L., M. Sharabi-Schwager, E. Feldmesser, R. Porat. 2011. Effects of ethylene degreening on the transcriptome of mandarin flesh. J. Postharvest Biol. Tech. 60: 75-82. 
Mayuoni, L., Z. Tietel, B.S. Patil, R. Porat. 2011. Does ethylene degreening affect internal quality of citrus fruit?. J. Postharvest Biol. Tech. 62(1): 50-58.

Muthmainnah, H., R. Poerwanto, D. Efendi. 2014. Perubahan warna kulit buah tiga varietas jeruk Keprok dengan perlakuan degreening dan suhu penyimpanan. J. Hort. Indonesia. 5(1): 10-20.

Napitupulu, B., B. Simatupang, A. Karo-karo, S. Simanjuntak, Sembiring. 1990. Pengaruh penggunaan ethrel terhadap mutu jeruk siem madu Brastagi selama penyimpanan. Buletin Pascapanen Hortikultura. 1(3): 7-12.

Pantastico, E.B. 1993. Fisiologi Pasca Panen. Yogyakarta, Penerjemah Kamarayani. Gadjah Mada University Press.

Peng, G., X.L. Xie, Q. Jiang, S. Song, C.J. Xu, 2013. Chlorophyll $\mathrm{a} / \mathrm{b}$ binding protein plays a key role in natural and ethyleneinduced degreening of ponkan (Citrus reticulate Blanco). J. Sci Hortic. 160: 37-43.

Poerwanto, R., A.D. Susila. 2014. Teknologi Hortikultura. Bogor, IPB Press.

Porat, R. 2008. Degreening of citrus fruit. Tree Forest. J. Sci Biotech. 2: 71-76.

Ramadhani, N., Y.A. Purwanto, R. Poerwanto. 2015. Pengaruh durasi pemaparan dan suhu degreening untuk membentuk warna jingga jeruk siam Banyuwangi. J Hort. 25(3): 277-286.

Rodrigo, M.J., B. Alquezar, E. Alos, V. Medina, L. Carmona. 2013. A novel carotenoid cleavage activity involved in the biosynthesis of citrus fruit-specific apocarotenoid pigments. J. Exp. Botany. 43: 14-22.
Shimokawa, K., S. Shimade, K. Yaeo, 1998 Ethylene-enhanced chlorophyllase activity during degreening of Citrus unshiu Marc. Sci. Hortic. 8: 129-135.

Stewart, I., T.A. Wheaton. 1972. Carotenoids in citrus: their accumulationinduced by ethylene. J. Agric. Food Chem. 20: 448449.

Sdiri, S., P. Navarro, A. Monterde, J. Benabda, A. Salvador. 2012. New degreening treatments to improve the quality of citrus fruit combining different periods with and without ethylene exposure. J Postharvest Biol. Tech. 63(1): 25-32. DOI: 10.1016/J.postharvbio.2011.08.005.

Sulistyaningrum, R.D., S. Susanto. 2004. Kualitas dan daya simpan buah jeruk Fremont (Citrus reticulata var. Fremont) yang dipanen dari tingkat ketinggian lahan yang berbeda. J. Agron Indonesia. 32(3): 21-27.

Tanaka, A., R. Tanaka. 2006. Chlorophyll metabolism. Curr. P. Bio. 9: 245-255.

Tietel, Z., W. Batia, E. Lewinsohn, E. Fallik, R. Porat. 2010. Improving taste and peel color of early-season Satsuma mandarins by combining high-temperature conditioning and degreening treatmens. $\mathrm{J}$. Postharvest Biol. Tech. 57: 1-5.

Winarno, F.G. 2002. Fisiologi Lepas Panen Produk Hortikultura. Bogor, Brio Press.

Zhou, Y.J., C.D. Sun, L.L. Zhang, X. Dai, C.J. $\mathrm{Xu}$, K.S. Chen. 2010. Preferential accumulation of orange-colored carotenoids in Ponkan (Citrus reticulata) fruit peel following postharvest application of ethylene or ethephon. J. Sci. Hort. 2: 229-235. 